\title{
Formation of laminated cyanobacterial mats in the absence of benthic fauna
}

\author{
Tom Fenchel * \\ Marine Biological Laboratory (University of Copenhagen), Strandpromenaden 5, DK-3000 Helsingør, Denmark
}

\begin{abstract}
Illuminated, defaunated shallow-water sediments develop cyanobacterial mats that in most details resemble stromatolitic mats previously described from hyperhaline habitats. These artificial mats grow continuously, increasing about $2 \mathrm{~mm}$ in thickness per year. The cyanobacterial mats are completely destroyed within 1 to 2 wk after colonisation by benthic animals. Specific representatives of the meiofauna and the macrofauna disrupt and ingest the cyanobacterial mats; bioturbation by larger animals also destroys the simple 1-dimensional vertical zonation patterns characteristic of microbial mats and thus their structural and functional integrity. The findings support the hypothesis that fossil stromatolites are rare in Phanerozoic deposits due to the activities of benthic animals which originated in the late Precambrian.
\end{abstract}

KEY WORDS: Cyanobacterial mats $\cdot$ Stromatolitic mats $\cdot$ Bioturbation $\cdot$ Animal grazing

\section{INTRODUCTION}

Stromatolitic cyanobacterial mats are known from hyperthermal habitats, Antarctic lakes, and from hyperhaline lagoons, including evaporating ponds for salt production. These structures often measure from several $\mathrm{cm}$ to more than $1 \mathrm{~m}$ in thickness although almost all biological activity is confined to the uppermost $5 \mathrm{~mm}$ (Cohen \& Rosenberg 1989, Schopf \& Klein 1992, Stal \& Caumette 1993 and references therein; see also Javor \& Castenholz 1981, Jørgensen et al. 1983). In addition to these relatively permanent microbial communities, ephemeral mats have been described from sheltered, shallow marine sediments in many localities (e.g. Fenchel \& Straarup 1971, Nicholson et al. 1987, van Gemerden et al. 1989). These usually measure $5 \mathrm{~mm}$ or less in thickness and their matrix consists of sedimentary particles held together by cyanobacterial filaments and by their mucous secretions, but they do not grow above the sediment surface. With respect to the taxonomic composition of the biota and to their functional properties, however, these mats closely resemble the upper mm

\footnotetext{
•E-mail: mbltf@inet.uni2.dk
}

of real stromatolitic mats from hyperhaline habitats. Typically they have a superficial golden-brownish layer composed mainly of eukaryotic algae and cyanobacteria covering a dark green layer dominated by filamentous cyanobacteria; beneath this a pink layer of purple sulphur bacteria occurs which again overlies a black sulphidic sediment. Such structures were described more than a century ago (e.g. Ørsted 1842) their characteristic colour lamination is responsible for their German name: 'Farbstreifen-sandwatt' (Schulz 1937)

Stromatolitic mats have long been considered modern analogues of Precambrian stromatolites. It has also drawn attention that their decline in the geological record in the late Precambrian coincides with the origin of metazoa (e.g. Garett 1970) and that modern stromatolitic mats occur in environments where metazoan life seems absent or limited. Also, the ephemeral mats of shallow marine sediments tend to develop in response to periodic (tidal) desiccation or to occasional anoxia in the overlying water column; these are factors which discourage metazoan activity.

Hyperthermal mats (> about $50^{\circ} \mathrm{C}$ ) are exclusively the domain of prokaryotes. However, hyperhaline stromatolitic mats and ephemeral mats on shallow sediments always include a variety of phagotrophic 
protists, probably always some representatives of the meiofauna, especially nematodes (Farmer 1992), and often also a few representatives of the macrofauna (Javor \& Castenholz 1981). The possible role of grazing and bioturbation in inhibiting the development of microbial mats has recently been reviewed (Farmer 1992). Studies have almost exclusively been confined to a few hyperhaline mats. Direct observations have shown that in hyperhaline tropical lagoons animals and especially cerithid gastropods inhibit mat formation on tropical shallow water sediments by grazing the sediment surface where the salinity is sufficiently low; various burrowing animals may then also disrupt mat lamination. Other studies, however, indicate that invertebrate grazing does not necessarily destroy stromatolitic mats (McNamara 1992). Under all circumstances, there appear to be no attempts to make more extensive experimentation, nor to follow the possible development of cyanobacterial mats in less exotic marine habitats in response to defaunation.

It is shown here that permanent and continuously growing stromatolitic mats develop on illuminated marine sediments from which metazoa have been removed and that particular representatives of the meioand macrofauna may completely destroy cyanobacterial mats within 1 to $2 \mathrm{wk}$. Two following papers (Fenchel 1998a, b) treat the physical structure and composition of the microbial community and element cycling of such artificial cyanobacterial mats.

\section{MATERIAL AND METHODS}

Sediments were collected in the innermost part of Nivå Bay (along the Danish coast of Øresund about $15 \mathrm{~km}$ south of Helsingør) at a depth of about $50 \mathrm{~cm}$. The sediment is well sorted sand (median grain size $-200 \mu \mathrm{m}$ ) and the salinity fluctuates between 15 and 20 ppt. The quantitative occurrence of the dominating macro- and meiofauna in a sediment core is shown in Table 1 (see also Fenchel 1969, 1996, Muus 1967). During warm weather in association with low water levels (resulting in periodic desiccation and water column anoxia during night) cyanobacterial mats frequently develop in the sand along the shore (Fenchel \& Straarup 1971), but these mats rarely persist more than a couple of weeks at a time. The sediments collected for the present study were collected further away from the shore; they are not affected as described above and they always harbour a dense and varied macro- and meiofauna. Several samples were collected with perspex cylinders (height about $10 \mathrm{~cm}$ and with internal diameters of either $5.5,7$ or $10 \mathrm{~cm})$ on 4 occasions $(24$ July, 4 September and 19 December 1996 and 3 June 1997).
Table 1. Example of the faunal composition of a non-frozen, 2 mo old core. Estimates of meiofauna are based on five $0.196 \mathrm{~cm}^{2}$ subsamples; the macrofauna figures were obtained by sieving the entire core $\left(38.5 \mathrm{~cm}^{2}\right)$

\begin{tabular}{|c|c|c|}
\hline & Numbers $\mathrm{cm}^{-2}$ & $\mathrm{SD}$ \\
\hline \multicolumn{3}{|l|}{ Meiofauna } \\
\hline Nematodes & 88.4 & 1.2 \\
\hline Turbellarians & 4.0 & 1.2 \\
\hline Oligochaetes & 1.4 & 0.8 \\
\hline Ostracods & 7.1 & 1.2 \\
\hline \multicolumn{3}{|l|}{ Macrofauna } \\
\hline Nereis diversicolor & 0.39 & \\
\hline Pygospio elegans & 0,21 & \\
\hline Corophium volutator & 0.23 & \\
\hline Hydrobia ventrosa & 0.10 & \\
\hline Mya arenaria (juv.) & 0.03 & \\
\hline
\end{tabular}

Initial attempts to defaunate the cores included adding sulphide $(10 \mathrm{mM})$ to the supernatant water, sealing the cores and leaving them in the dark for 10 to $30 \mathrm{~h}$. While successfully killing most macro- and meiofaunal constituents, some individuals or their resistant eggs (including representatives of the nematodes, oligochaetes, harpacticoids and other meiofauna) survived and dense populations belonging to one or more species usually appeared after some weeks. Cyanobacterial mats which had started to develop were then often destroyed. These experiments did, however, allow for observations on the effect of particular meiofaunal species on the mats. A method which proved efficient in removing all macrofauna and meiofauna (except for an unidentified nematode species and the rotifer Colurella) was to leave the sediment samples in a freezer $\left(-20^{\circ} \mathrm{C}\right)$ for $20 \mathrm{~h}$. The frozen and unfrozen (control) cores were placed separately in aquaria with autoclaved, air-bubbled seawater (salinity: $-18 \mathrm{ppt})$ in a thermostat-controlled $\left(17^{\circ} \mathrm{C}\right)$ room and exposed to a $10 \mathrm{~h}$ dark:14 h light cycle. Illumination was based either on two $30 \mathrm{~W}$ fluorescent tubes + two $60 \mathrm{~W}$ incandescent bulbs or on $120 \mathrm{~W}$ halogen lamps. Incident illumination on the sediment surface was approximately $300 \mu \mathrm{E} \mathrm{m}^{-2} \mathrm{~s}^{-1}$ in either case. When halogen lamps were used, the temperature of the water rose to about $25^{\circ} \mathrm{C}$ during illumination. Some of the frozen cores were covered by a 0.4 or $1.0 \mathrm{~cm}$ thick layer of foam rubber so that the mats grew in and on this material; this allows for later histological sectioning of fixed and embedded cyanobacterial mats (Fenchel 1998a).

Chlorophyll a and bacteriochlorophyll a were quantified by taking subcores (diameter $0.5 \mathrm{~cm}$ ) down to a depth of $5 \mathrm{~mm}$. These were sectioned vertically in $1 \mathrm{~mm}$ thick slices which were extracted in $3 \mathrm{ml}$ methanol. Concentrations were estimated spectrophotometrically assuming extinction coefficients of 89.4 l 

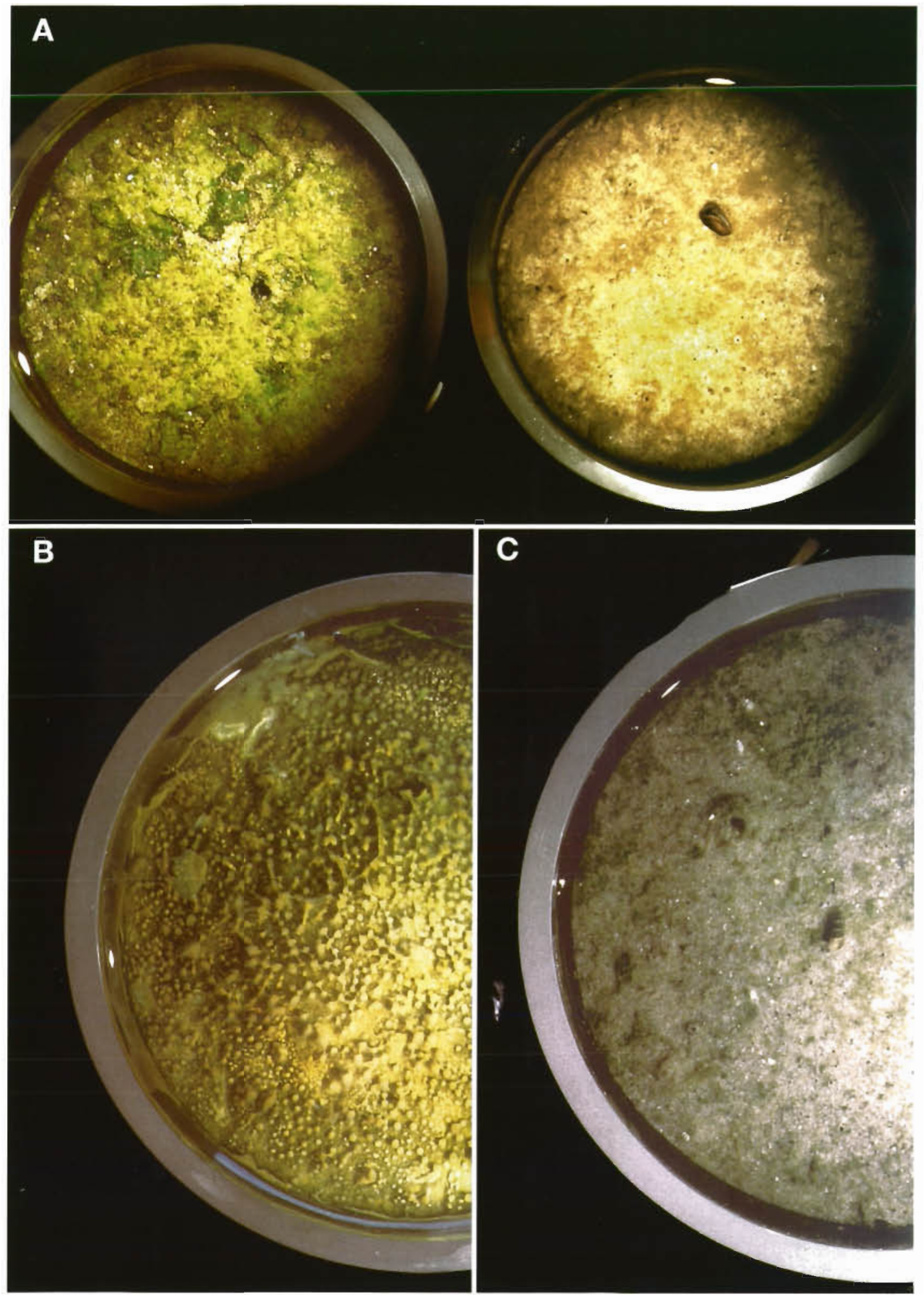

Fig. 1. (A) A defaunated core (left) and a control core (right). The cores are 3 mo old; in the defaunated core the developing cyanobacterial mat has encrusted the superficial sediment layer which can be broken off as coherent flakes. Core diameter: $7 \mathrm{~cm}$. (B) A 4 mo old cyanobacterial mat now growing above the sediment and showing the characteristic gelatinous pinnacle structure (C) The same core about a month after colonisation of the normal fauna; a few green faecal pellets is all that remains of the mat. Core diameter: $10 \mathrm{~cm}$ 
$\mathrm{cm} \mathrm{g}^{-1}$ (chlorophyll a, $665 \mathrm{~nm}$ ) and $84.1 \mathrm{I} \mathrm{cm} \mathrm{g}^{-1}$ (bacteriochlorophyll $a, 770 \mathrm{~nm}$ ). The $0.5 \mathrm{~cm}$ subcores were also used to monitor the vertical growth of the mats and to study live samples of the microbial biota (see Fenchel 1998a).

In order to study the effect of introducing fauna to microbial mats, a faunated core and a core with an established (>4 mo old) cyanobacterial mat were placed together in 1 aquarium; the subsequent colonisation and fate of the mat was then studied over the following weeks.

\section{RESULTS AND DISCUSSION}

The faunated cores remained unchanged with respect to the qualitative composition of the fauna, but individual growth of some species (especially of the polychaete Nereis diversicolor) was evident; probably as a result of this, chlorophyll contents, photosynthesis and $\mathrm{O}_{2}$ uptake of the cores (not shown) slowly declined over the first 6 mo. There was never any macroscopically visible surface growth of phototrophs.

The previously frozen cores developed a veil of colourless sulphur bacteria during the first couple of days followed by a layer of purple sulphur bacteria. After a week a thin film consisting of filamentous cyanobacteria and some eukaryotic algae was already evident. After a few weeks the mineral grains of the upper mm were held together by a matrix of filamentous cyanobacteria which covered a purple layer of sulphur bacteria; this stage very much resembled the natural mats which occasionally develop in shallow water along the shore during the summer (see Fig. 1A). During the subsequent months the mats became thicker and grew above the sediment. After about 3 wk the surface became gelatinous with a few mm tall pinnacles rising 1 to $3 \mathrm{~mm}$ above the surface and with blisters resulting from the formation of $\mathrm{O}_{2}$ bubbles during illumination (Fig. 1B; see also Fenchel 1998a). The mat then had a rubber-like consistency, but eventually hardened due to carbonate deposition about $200 \mu \mathrm{m}$ below the surface. After a year the entire mat (including the underlying purple layer) was then about $7 \mathrm{~mm}$ and extended about $2 \mathrm{~mm}$ above the mineral sediment/foam rubber surfaces (Fig. 2). An increment of about $2 \mathrm{~mm} \mathrm{yr}^{-1}$ is consistent with estimates from natural stromatolitic mats: $1.2 \mathrm{~mm} \mathrm{yr}^{-1}$ for Solar Pond, Egypt (Jørgensen \& Cohen 1977) and 4 to $10 \mathrm{~mm} \mathrm{yr}^{-1}$ for Laguna Guerrero Negro, Mexico (Javor \& Castenholz 1981). The concentration of chorophylls increased during the first 2 to 3 mo and thereafter remained constant (Fig. 3); in contrast to the faunated cores almost all chlorophyll a was concentrated in the upper 3 to $4 \mathrm{~mm}$ (Fig. 4). Cyanobacterial biofilms also developed

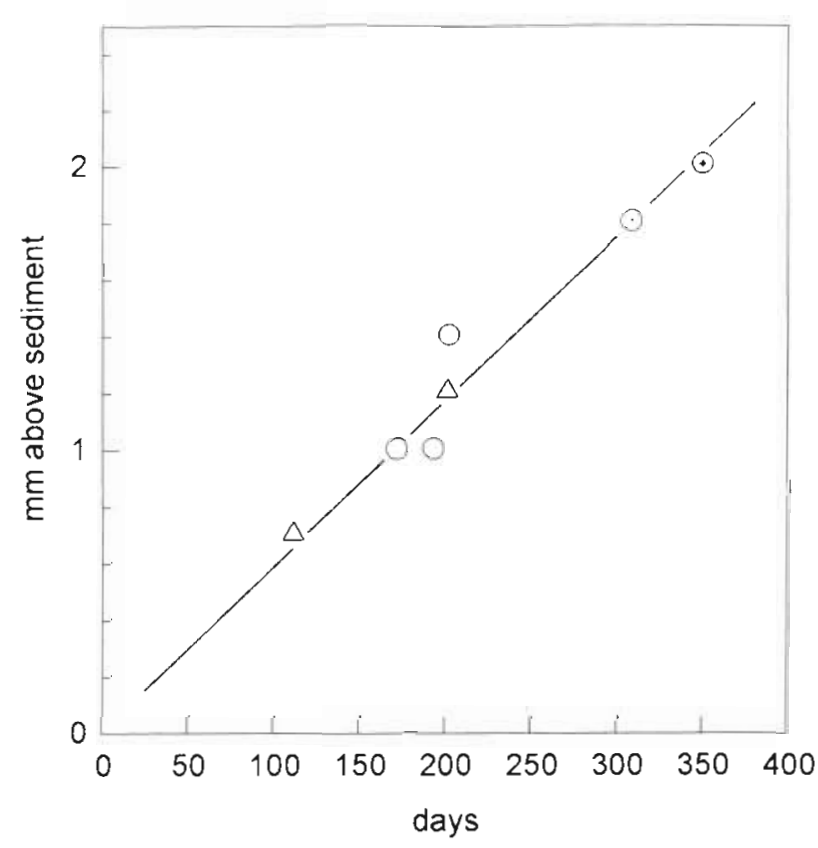

Fig. 2. Growth of artificial cyanobacterial mats measured as the thickmess above the original sediment surface (symbols refer to different individual cores; $\triangle$ : foam rubber 'sediment'; the others are growing on natural sediments)

on the walls of the aquaria, but these grew slowly and did not form the characteristic laminations: the presence of an anaerobic sulphidic base appears to be necessary for the maturation of thick mats.

The mats always included a variety of phototrophic and heterotrophic protists (diatoms, euglenoids, heterotrophic flagellates, amoebae and some ciliates) in addition to the dominating cyanobacteria and other prokaryotes. All mats also harboured an unidentified nematode and frequently a rotifer. It is likely that most of these components have some sort of freezing-resis-

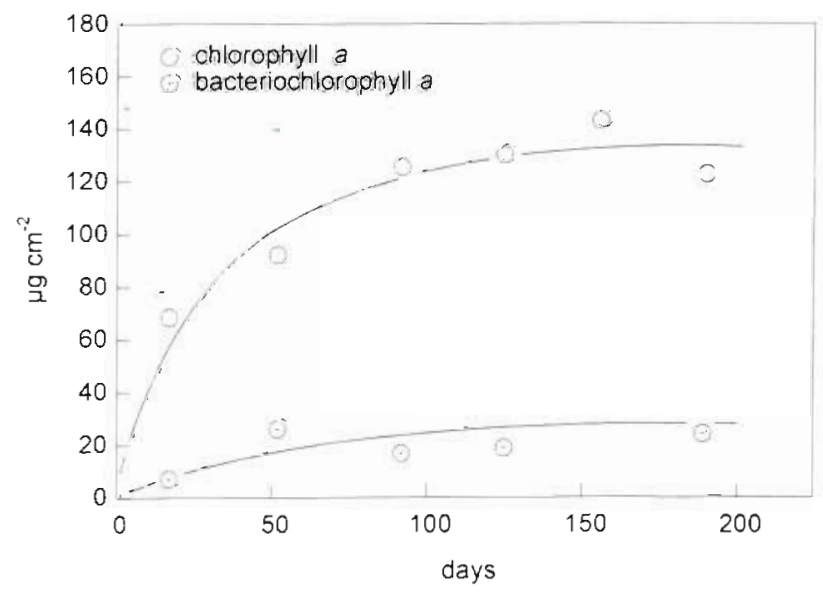

Fig. 3. Increase in chlorophyll a and bacteriochlorophyll $a$ in a developing cyanobacterial mat 


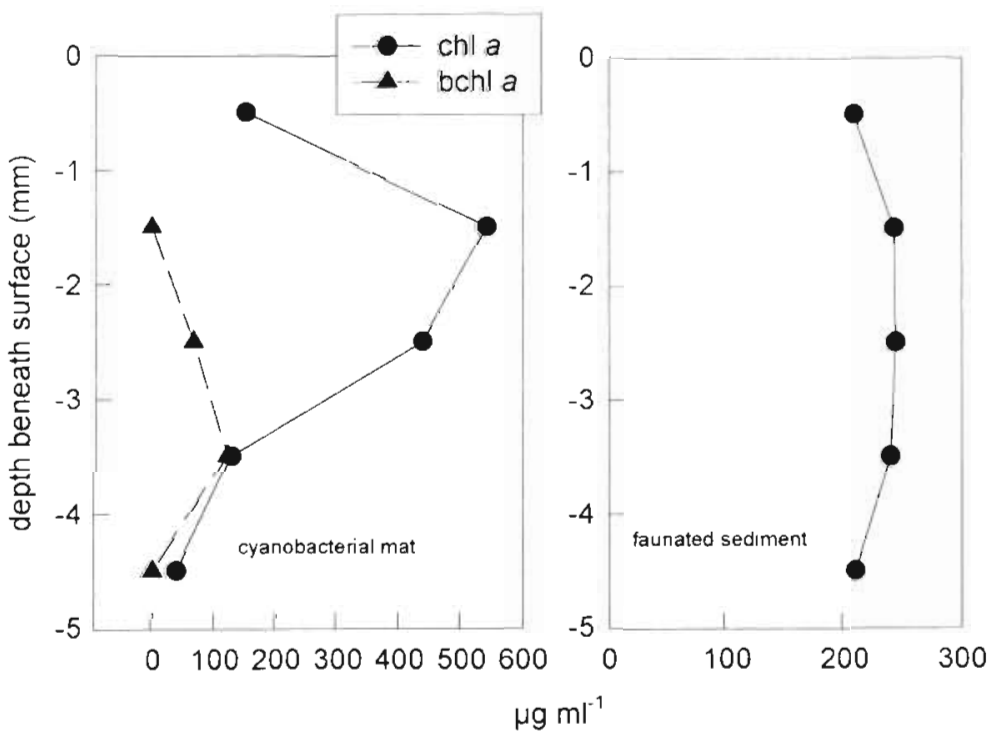

Fig. 4. Vertical distribution of chlorophylls in a cyanobacterial mat and a faunated sediment

tant resting stages. In some mats a harpacticoid copepod (probably Harpacticus sp.) appeared after several months; this may be due to accidental contamination. However, none of these eukaryote components seemed to feed on filamentous cyanobacteria or in any other way have a detrimental effect on the development of the mats.

In a sulphide treated core with a developing cyanobacterial mat a dense population of the harpacticoid

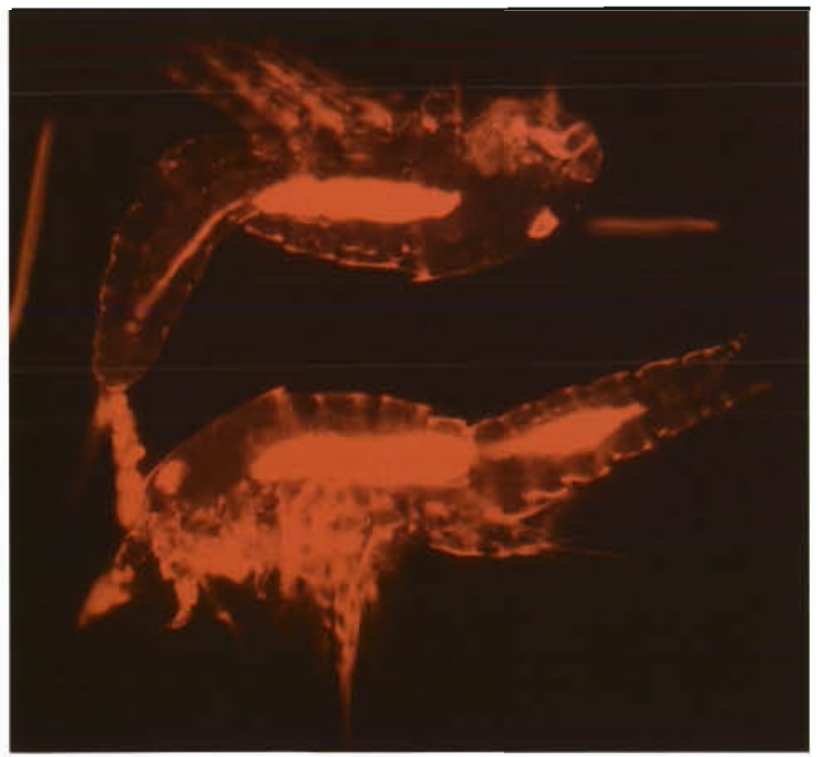

Fig. 5. Two specimens of a harpacticoid copepod (Nitocra sp.) with their intestines filled with ingested cyanobacterial filaments. The copepods were photographed in the fluorescence microscope using green excitation light; the red fluorescence is due to the phycoerythrin contents of the food copepod Nitocra appeared after about a month. A week after the copepods had been observed the mat was totally disintcgrated. Microscopic observations confirmed that the copepods almost exclusively ate cyanobacterial filaments (Fig. 5), eventually leaving the entire mat in the form of faecal pellets.

A 4 mo old mat became colonised by meiofauna, hydrobiid snails and nereid worms within $3 \mathrm{~d}$ after a faunated core was placed in the tank and after 2 wk the faunal composition in the 2 cores was identical. By that time the snails and in particular the polychaetes had ingested the entire mat and converted it into green faecal pellets which eventually disintegrated and disappeared (Fig. 1C). Total chlorophyll contents decreased to about $25 \%$ of the initial value (Fig. 6) and the remaining chlorophyll was evenly distributed in the upper mm of the core. The chemical zonation of the mats (Fenchel 1998b) was also destroyed and replaced by a complex matrix of oxic and anoxic patches in the upper $\mathrm{cm}$ of the sediment due to the presence of ventilated worm burrows (cf. Fenchel 1996).

The presented observations show that a normal marine shallow water sediment has the potential to develop typical stromatolitic mats known otherwise only from more exotic habitats. While the development of such mats is compatible with the presence of certain meiofauna species, others are consumers of cyanobacteria, as are several larger animals (nereid worms,

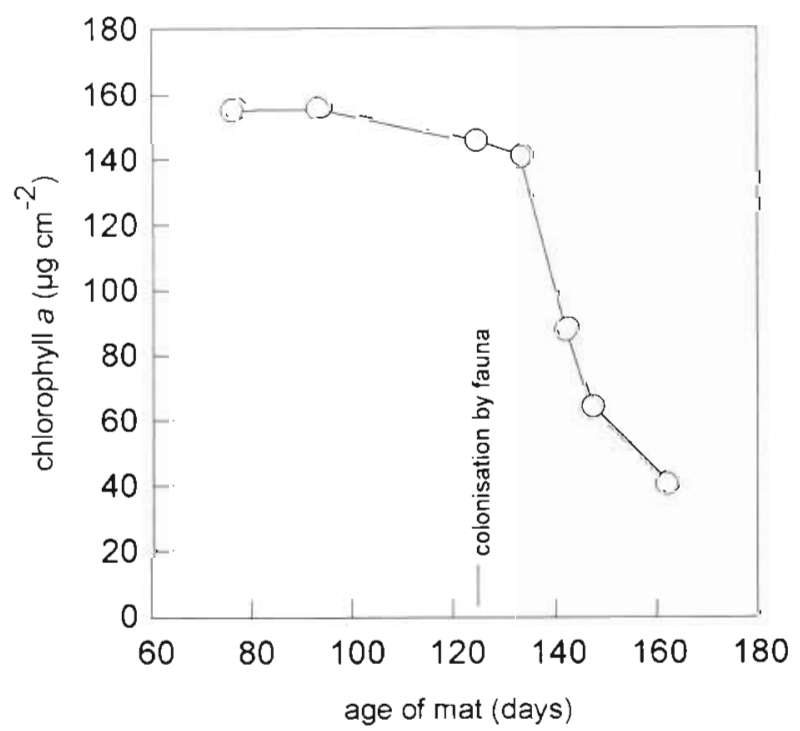

Fig. 6. Chlorophyll a in a cyanobacterial mat before and after colonisation by animals 
hydrobiid snails), and the extremely slowly growing microbial mat community cannot cope with grazing. The integrity and structure of cyanobacterial mats is maintained by vertical gradients of light and of chemical species and by diffusive fluxes. Animals which mix the surface sediments (e.g. hydrobiid snails) or form ventilated burrows (e.g. nereid polychaetes) also destroy these patterns and thus prevent mat formation.

Acknowledgements. These studies were supported by a grant from the Danish Natural Science Research Council. I am grateful to Ms Jeanne Johansen for technical assistance.

\section{LITERATURE CITED}

Cohen Y, Rosenberg E (eds) (1989) Microbial mats. American Society for Microbiology, Washington, DC

Farmer J (1992) Grazing and bioturbation in modern microbial mats. In: Schopf JW, Klein C (eds) The proterozoic biosphere. Cambridge University Press, New York, p 295-297

Fenchel T (1969) The ecology of marine microbenthos. IV. Structure and function of the benthic ecosystem, its chemical and physical factors and the microfauna communities with special reference to the ciliated protozoa. Ophelia 6 : $1-182$

Fenchel T (1996) Worm burrows and oxic microniches in marine sediments. 1. Spatial and temporal scales. Mar Biol $127: 289-295$

Fenchel T (1998a) Artificial cyanobacterial mats: structure and composition of the biota. Aquat Microb Ecol 14:241-251

Fenchel T (1998b) Artificial cyanobacterial mats: cycling of $C$, $O$ and S. Aquat Microb Ecol 14:253-259

Editorial responsibility: Gary King

Walpole, Maine, USA
Fenchel T, Straarup BJ (1971) Vertical distribution of photosynthetic pigments and the penetration of light in marine sediments. Oikos 22:172-182

Garett P (1970) Phanerozoic stromatolites: noncompetitive restriction by grazing and burrowing animals. Science 169:171-173

Javor BJ, Castenholz RW (1981) Laminated microbial mats, Laguna Guerrero Negro, Mexico. Geomicrobiol J 2: $237-273$

Jørgensen BB, Cohen Y (1977) Solar Lake (Sinai). 5. The sulfur cycle of the benthic cyanobacterial mats. Limnol Oceanogr 22:657-666

Jørgensen BB, Revsbech NP, Cohen Y (1983) Photosynthesis and structure of benthic microbial mats: microelectrode and SEM studies of four cyanobacterial communities. Limnol Oceanogr 28:1075-1093

McNamara K (1992) Stromatolites. Western Australian Museum, Perth

Muus BJ (1967) The fauna of Danish estuaries and lagoons. Medd Danmarks Fiskeri-Havunders NS 5:1-316

Nicholson JAM, Stolz JF, Pierson BK (1987) Structure of a microbial mat at Great Sippewissett Marsh, Cape Cod, Massachusetts. FEMS Microbiol Ecol 45:343-364

$\varnothing$ rsted AS (1842) Beretning om en Excursion til Trindelen. Naturhist Tidsskrift 3:552-569

Schopf JW, Klein C (eds) (1992) The proterozoic biosphere. Cambridge University Press, Cambridge

Schulz E (1937) Das Farbstreifen-sandwatt und seine Fauna, eine ökologische biozönotische Untersuchung an der Nordsee. Kieler Meeresforsch 1:359-378

Stal LJ, Caumette P (eds) (1993) Microbial mats. SpringerVerlag, Berlin

van Gemerden H, Tughan CS, de Wit R, Herbert RA (1989) Laminated microbial ecosystems on sheltered beaches in Scapa Flow, Orkney Islands. FEMS Microbiol Ecol 62: $87-102$

Submitted: September 13, 1997; Accepted: December 22, 1997 Proofs received from author(s): March 9, 1998 